\title{
Public Service Innovation and Evaluation Indicators
}

\author{
Silvia Cruz', Sônia Paulino²
}

\begin{abstract}
This paper analyzes innovation in public services with emphasis on the application of evaluation indicators. It considers the clean development mechanism (CDM) projects developed in the Bandeirantes and São João landfills, both located in the city of São Paulo, Brazil. There are two methodological procedures. First, the analysis is based on a multi-agent innovation approach. Second, there is an adaptation of the social carbon methodology (SCM) constructing indicators to assess the social and environmental outcome of landfill CDM projects in order to identify opportunities for innovations in services related to the solid waste sector. The application of the multi-agent model for innovation in public services in the solid waste sector makes it possible to bring together the political actors, service organizations and consumers / users. Equally pertinent is the adaptation of the application of SCM, defining indicators to understand the particularities of the service in the context researched, with regard to seeking opportunities for building new ways to solve specific problems through new institutional and organizational arrangements, involving municipal governments, utility companies, communities surrounding the landfills, collectors of recyclable materials, organized bodies of civil society; and with regard to establishing parameters to guide the objectives of innovation in the public sector.
\end{abstract}

Keywords: clean development mechanism; service innovation; urban solid waste sector; sustainability evaluation indicators.

\footnotetext{
'Department of Science and Technology Policy, Institute of Geosciences (IG), State University of Campinas (Unicamp), P.O. box 6I52, I3083-970, Campinas, SP, Brazil. e-mail: silviacruz@ige.unicamp.br

${ }^{2}$ Environmental Management, School of Arts, Sciences and Humanities, University of São Paulo (USP),.Av.Arlindo Bettio, I000, São Paulo-SP 03828-000, Brazil. e-mail: sonia.paulino@usp.br
} 


\section{Introduction}

This paper analyzes innovation in public services with emphasis on the application of evaluation indicators. It considers the clean development mechanism projects developed in the Bandeirantes and São João landfills, both located in the city of São Paulo, Brazil. These landfills were selected for this study due to the similar characteristics of the projects, and because both are located in a city of great complexity in terms of the role of local government management. In addition, $50 \%$ of the CER (certified emission reduction) revenues are allocated to the municipal City Hall, specifically for the Environment and Sustainable Development Fund FEMA, which is administered by the Municipal Secretariat for the Environment.

The Kyoto Protocol (KP) was established in 1997, following an agreement reached at the third Conference of the Parties of the United Nations Framework Convention on Climate Change (UNFCCC). This Protocol states that the countries included in Annex I, comprising the industrialized countries which in 1992 were OECD members, and countries with developing economies, should reduce their emission levels of greenhouse gases (GHG) to targets that are mainly set below their 1990 levels, by at least $5 \%$, over the period 2008 to 2012.At COP-18, held in Doha, Qatar, in December 2012, it was confirmed that the Kyoto Protocol would continue until 2020.

To assist the countries in Annex I in attaining their GHG emission reduction goals, the Protocol establishes three flexibility mechanisms. The mechanisms referred to as "joint implementation" and "emissions trading" are restricted to the countries in Annex I. Therefore, CDM is the most important mechanism in the Brazilian context, which entails the implementation in emerging and developing countries of project activities that reduce GHG emissions, resulting in certified emission reductions (CER), popularly known as 'carbon credits', which may be purchased by countries listed in Annex I, assisting them in part fulfillment of their targets agreed upon their ratification of the Kyoto Protocol.

The Protocol highlighted the following GHGs as the principal causes of climate change: carbon dioxide (CO2), methane (CH4), nitrous oxide (N2O), perfluorocarbons (PFCs), hydrofluorocarbons (HFCs), and sulfur hexafluoride (SF6). From the global warming potential (GWP) of each gas, a value that estimates the potential contribution of each gas to global warming, it is possible to measure the CER through conversion to the standard unit sets in tons of carbon dioxide equivalent ( $\mathrm{tCO} 2 \mathrm{e}$ ). Thus, the CER corresponds to the reduction - or non-emission - of a $\mathrm{tCO} 2 \mathrm{e}$ and may be commercialized under the carbon market regulated by Kyoto Protocol.
CDM includes activities of GHG emission reduction projects established in a wide variety of sectors, including landfills. These projects have great potential for GHG reduction, since due to the bacterial decomposition of the organic fraction of solid waste, under anaerobic conditions, methane is produced, a GHG with a global warming potential 21 times greater than carbon dioxide, and consequently, with potential to generate a large amount of carbon credits.

Out of the 269 Brazilian CDM projects, 38 are developed on landfills, 20 of which are located in the State of São Paulo (UNEP RISOe, March 2013).

In the Brazilian context, few landfills utilize biogas (methane) for burning or power generation, and those landfills that do perform these activities are sites with CDM projects. The common practice, in Brazil and throughout the world, is to let the gas escape directly into the atmosphere through collector drains. Therefore, the implementation of this type of project is considered a differential between landfills, since it offers the potential to go beyond GHG reductions and contribute positively to local development.

In Brazil, the aspects related to sustainable development that CDM projects should also promote, are presented in a separate document, based on Annex III of Resolution No. I of the Interministerial Commission on Global Climate Change (CIMGC), which establishes the local co-benefits or project activity contributions for each of the five aspects relating to sustainability: I) local environmental sustainability; 2) development of working conditions and employment generation; 3) income distribution; 4) training and technological development; and 5) regional integration and links with other sectors (Brazil, 2003).

Project approval is the responsibility of the Designated National Authority (DNA) and is subject to the analysis of the project in the light of the rules and regulations of the CDM Executive Board, with emphasis on the activity's sustainability aspects, as set out in Annex III of Resolution No. I of the CIMGC.

The importance of the effective participation of civil society throughout the approval process should be noted. Therefore, another important action that the project proponents are obliged to undertake is to send letters of invitation to the stakeholders, at the very least including the following actors: the City Hall involved; the city council of each municipality involved; the state environmental agency; the local environmental agency; the Brazilian Forum of NGOs and Social Movements; community associations with a direct or indirect relationship with the project activity; the state prosecutor; and the federal prosecutor. 
Based on the scenario outlined above, the question arises as to how to evaluate the social and environmental local co-benefits generated by Landfill CDM projects, given that, in contrast to emission reductions, which are monitored and checked periodically by the certifying bodies, the sustainable development contribution of CDM projects requires regulatory aspects that define procedures to monitor and ensure its effectiveness.

Thus, in the first instance, this research analysis is based on a multi-agent innovation approach [Windrum, P., Garcia-Goñi, M. (2008), A neo-Schumpeterian model of health services innovation, Research Policy, 37, 649-672] directed at learning about the interactions between the different agents. Secondly, an adaptation of the social carbon methodology (SCM) is proposed, elaborating indicators to assess the social and environmental outcomes of CDM landfills in order to identify opportunities for service innovations related to urban solid waste sector.

The concept of Social Carbon arose from the need to guarantee that projects to reduce GHG could encompass issues of sustainable development, and to develop a transparent means of measuring social gains from the projects. It was constructed during the implementation of a carbon sequestration project at and around Illha do Bananal, Tocantins State, Brazil. Since then, the Social Carbon approach has been evaluated and improved. Over the past ten years, various organizations and communities have worked together on climate change mitigation projects in an effort to reach satisfactory standards for developing indicators of sustainability [For more information: http://www.socialcarbon.org/.] The paper is structured in four sections. Following the introduction, section two summarizes a review of the literature highlighting the potential of landfill CDM projects to contribute to the promotion of public services innovations. In this same section, the public sector innovation issue is addressed and subsequently, the indicators and the development of social carbon methodology. Section three describes the method applied, while section four presents the results. Final considerations are stated in the concluding section 5 .

\section{Literature Review}

This section is structured to introduce the process of CDM, focusing on landfill projects. Following this, the specific characteristics of public sector innovation are presented, as well as the driving factors and relevance for innovation in this sector. Subsequently, there follows an outline of the SCM components required to achieve the purpose of social and environmental evaluation of projects to reduce greenhouse gases (GHG) emissions that are proposed by SCM, and demonstrate what this methodology has consolidated so far in terms of indicators for different sectors and certified projects.

\section{Landfills Clean Development Mechanism (CDM) projects}

In Brazil, CDM projects began in June 2004 with the approval of the Nova Gerar project, in the Baixada Fluminense district, Rio de Janeiro State, and the Veja project in Salvador, Bahia State, both in order to generate energy through the use of biogas from landfills. The landfills projects developed in Brazil are shown in Table I.

Brazil has a significant potential for carbon credits generation in the area of landfills, given the initiatives already underway, constituting a promising opportunity to promote social and environmental sustainability in the country, supporting the appropriate solid waste management system, given that these projects need to be linked to a solid waste policy that encourages practices such as environmental education, reuse, recycling and reduction, benefiting also the generation of biogas.

\section{Public Service Innovation}

According to Bhatta (2003), incentives to innovate in the public sector are lower, and the risks greater, than in the private sector. Therefore, innovations in public services should be seen as a fundamental activity aimed at increasing the services' capacity to respond to local and individual needs; as well as to monitor the needs and expectations of the target groups (Mulgan and Albury, 2003).

The Schumpeterian definition of innovation is directly focused on market competition through innovation. However, this incentive is less important in the context of innovation in the public sector (Potts and Kastelle, 2010).

One of the main differences is that public sector organizations do not operate within a market framework and are therefore not geared to the pursuit of profit. Although this statement is true for the most part, it nevertheless reflects a simplistic vision of "public affairs", given that their incentive structures are shaped by much more than profit maximization.

Futhermore, although public sector organizations are not geared to profit maximization, they have goals, and when these goals are not met there are negative consequences (Koch and Hauknes, 2005). As an organizational field, the public sector is guided also by principles of economic efficiency, aiming to minimize waste and maximize results with a limited budget (Potts, 2009).

The risk aversion culture can also be linked to limited budgets. This culture has been identified in the public sector as a factor that can affect the innovation process, since the public

ISSN: 07 I8-2724. (http://www.jotmi.org)

Journal of Technology Management \& Innovation (c) Universidad Alberto Hurtado, Facultad de Economía y Negocios. 


\begin{tabular}{|c|c|}
\hline Landfill project title & Localization \\
\hline Nova Gerar landfill gas & Rio de Janeiro \\
\hline Salvador, Bahia - landfill gas & Bahia \\
\hline Onyx landfill gas - Trémembé, Brazil & São Paulo \\
\hline MARCA landfill gas & Espírito Santo \\
\hline Bandeirantes landfill gas & São Paulo \\
\hline ESTRE Paulínia landfill gas & São Paulo \\
\hline Caieiras landfill gas & São Paulo \\
\hline Lara landfill & São Paulo \\
\hline São João landfill gas & São Paulo \\
\hline Anaconda Project & São Paulo \\
\hline Central de Resíduos do Recreio - landfill gas project & Rio Grande do Sul \\
\hline Canabrava landfill gas & Bahia \\
\hline Aurá landfill gas & Pará \\
\hline ESTRE Itapevi landfill gas & São Paulo \\
\hline Quitaúna landfill gas & São Paulo \\
\hline Estre Pedreira landfill gas & São Paulo \\
\hline URBAM/ARAUNA landfill gas & São Paulo \\
\hline Embralixo/Araúna - Bragança landfill gas & São Paulo \\
\hline Probiogas - João Pessoa landfill gas & Paraíba \\
\hline Terrestre Ambiental landfill gas & São Paulo \\
\hline CTRVV landfill gas & Espírito Santo \\
\hline Alto-Tietê landfill gas & São Paulo \\
\hline Feira de Santana landfill gas & Bahia \\
\hline Proactiva Tijuquinhas landfill gas & Santa Catarina \\
\hline Central-CTRS/BR.040 landfill gas & Minas Gerais \\
\hline SANTECH - Saneamento \& Tecnologia Ambiental Ltda. - SANTEC landfill gas & Santa Catarina \\
\hline Organoeste Dourados \& Andradina & Mato Grosso do Sul e São Paulo \\
\hline Manaus landfill gas & Amazonas \\
\hline Itaoca landfill gas & Rio de Janeiro \\
\hline CTR Candeias landfill gas & Pernambuco \\
\hline Central de Tratamento de Resíduos Leste (CTL) landfill gas & São Paulo \\
\hline Uberlândia landfills I and II & Minas Gerais \\
\hline CGR Guatapara Landfill Project & São Paulo \\
\hline Natal Landfill Gas to Energy Project & Rio Grande do Norte \\
\hline Projeto de Gás de Aterro TECIPAR - PROGAT & São Paulo \\
\hline ENGEP \& BEGREEN CDM Project at UTGR - Jambeiro Landfill & São Paulo \\
\hline Barueri Energy CDM Project Activity & São Paulo \\
\hline Constroeste Landfill Gas to Energy Project & São Paulo \\
\hline
\end{tabular}

Table I. Brazil CDM projects in landfills - March 2013. Source: the authors, based on UnepRisoe Pipeline (March 2013). 
sector cannot easily build experimental laboratories to test a new service, system, or policy (Mulgan and Albury, 2003).

Authors such as Potts and Kastelle (2010) and Stoker (2010) point out that the experimental approach could facilitate discoveries concerning public sector innovation. The challenge remains to discover mechanisms that really work in order to attain innovation goals in the public sector. Although experimental approaches with regard to public sector innovation are singled out as a solution, to date, this has scarcely been mentioned in the literature on public sector innovation.

Public sector innovation is increasingly seen as a key factor in sustaining an adequate level of public services for citizens and for companies. However, the lack of quantitative data (social, financial, the use of resources, and other factors) limits the capability of understanding and promoting innovation in the public sector (Bugge et. al., 20I0).

Despite the efforts carried out so far, the nature and characteristics of public services, remain nebulous. In part, this is a reflection of their highly dynamic attribute in terms of growth and change. It is also associated with the lack of experimental approaches from research on innovation, especially in the public sector. This is an emerging research field focused on complex and multi-dimensional problems.

\section{Indicators and the social carbon methodology (SCM)}

In recent decades, the development and application of indicators were introduced as an important tool for the analysis and interpretation of a specific reality. According to the Organization for Economic Cooperation and Development (OECD), an indicator needs to be understood as a parameter, or a value resulting from parameters that provides information about the condition of a phenomenon (OECD, 1993).

According to Rodrigues et al. (2006), the indicators important for the understanding of complex systems have four main functions: 1) To synthesize large volumes of information; 2) To show the current situation in relation to desired situations; 3 ) To demonstrate progress towards goals and objectives; and 4) to inform the stakeholders of the current situation in order to assist in the decision-making aimed at complying with the standard outlined. Having highlighted these elements, the Social Carbon Methodology (SCM) will be presented, which proposes the use of sustainability indicators to be applied to carbon market projects.

SCM was designed by the Instituto Ecológica (IE) [Founded in 2000, IE is an OSCIP (Civil Society Organization of Public Interest) whose mission is to act in reducing the effects of climate change, through scientific research, environment conservation and support the sustainable development of the communities] from a socio-environmental project carried out at the Bananal Island, in the State of Tocantins, Brazil, with resources from companies interested in promoting environmentally responsible activities, made possible through negotiations regarding funding of carbon sequestration projects. Since 2000 , the methodology has been applied in various sectors, with experience in the areas of energy efficiency, renewable biomass, biofuels, and reforestation, among others.

SCM is applied to carbon projects in parallel with another standard, since its scope proposes to evaluate only the social and environmental performance of the projects, and not the verification and quantification of emission reductions (Galt, 2010). Therefore, SCM focuses on discovering the social and environmental co-benefits of these projects. Within the ambit of the voluntary carbon market, SCM is usually used in conjunction with a carbon offset standard, the Verified Carbon Standard (VCS ), in order to quantify the emission reductions of the projects evaluated.

Given the ability that SCM has to assess and monitor the social and environmental sustainability of carbon projects, this research intends to use it to analyze the landfill CDM projects, considering that these projects have the potential to promote improvements in the municipal solid waste sector; however it is necessary to examine closely what is described in the documents of the projects which is based on Annex III of Resolution No. I of the CIMGC.

It should also be noted that, although the CDM project descriptions related to sustainable development are presented according to Annex III rules, these aspects are still not significant in Brazilian projects. One solution aimed at solving this issue would be the existence of a more accurate verification of this aspect, in order to include it effectively in the activities of the projects. Therefore, SCM might be a tool that helps in that direction. SCM is based on the resources described in the Table 2 .

From the definition of the resources, sustainability indicators are established to identify the degree to which resources are used, always beginning with the most precarious situation (unsustainable use) and ending with the most complete situation (sustainable use) (Rezende and Merlin, 2003). As demonstrated by Figure I.

The results obtained are represented in the form of a hexagon, based on the resources described previously, as shown in Figure 2. With the hexagon, it is possible to evaluate and monitor the project performance analysis over time. 


\begin{tabular}{|l|l|}
\hline Resource & Description \\
\hline Technology & $\begin{array}{l}\text { This evaluates the conditions of access to technology assets, } \\
\text { including equipment and process innovation, focused on their } \\
\text { contribution to economic, social and environmental aspects. }\end{array}$ \\
\hline $\begin{array}{l}\text { Biodiversity } \\
\text { [The biodiversity resource is replaced by } \\
\text { the technology when it is considered an } \\
\text { essential factor for the project's sustain- } \\
\text { ability] }\end{array}$ & $\begin{array}{l}\text { This represents the set of species, ecosystems and genes that } \\
\text { constitute the biological diversity. Essentially, the balance of the } \\
\text { natural physical environment. }\end{array}$ \\
\hline Natural & $\begin{array}{l}\text { This is the relationship between the enterprise and the stock of } \\
\text { natural resources and environmental services from which they } \\
\text { derive the resources to generate a livelihood. }\end{array}$ \\
\hline Financial & $\begin{array}{l}\text { This is the basic capital and other economic assets available to the } \\
\text { people. Also the physical and technological infrastructures that } \\
\text { create financial turnover. }\end{array}$ \\
\hline Human & $\begin{array}{l}\text { These are the skills, knowledge and capacity for work and for life } \\
\text { that people have, in addition to good health. Essential items to } \\
\text { ensure the operation of the enterprise. }\end{array}$ \\
\hline Social & $\begin{array}{l}\text { This encompasses actions of social responsibility, in addition to } \\
\text { the labor network, social demands, social relations, relationships } \\
\text { with the communities, associations and social organizations. }\end{array}$ \\
\hline Carbon & $\begin{array}{l}\text { This regards the type of carbon project developed, embracing } \\
\text { methodologies, project performance and stakeholder involvement. }\end{array}$ \\
\hline
\end{tabular}

Table 2. SCM resources. Source: the authors, based on Rezende and Merlin (2003).

\begin{tabular}{|l|l|l|l|l|l|l|}
\hline & \multicolumn{2}{|c|}{ UNSUSTAINABLE } & RESOURCE & \multicolumn{2}{|c|}{ SUSTAINABLE } & \\
\hline & & & & & & \\
\hline Indicator 01 & Scenario 01 & Scenario 02 & Scenario 03 & Scenario 04 & Scenario 05 & Scenario 06 \\
\hline Indicator 02 & $\ldots$ & $\ldots$ & $\ldots$ & $\ldots$ & $\ldots$ & $\ldots$ \\
\hline Indicator 03 & $\ldots$ & $\ldots$ & $\ldots$ & $\ldots$ & $\ldots$ & $\ldots$ \\
\hline$\ldots$ & $\ldots$ & $\ldots$ & $\ldots$ & $\ldots$ & $\ldots$ & $\ldots$ \\
\hline
\end{tabular}

Figure I. Representation of the indicators and their Scenarios. Source: the authors, based on Rezende and Merlin (2003)

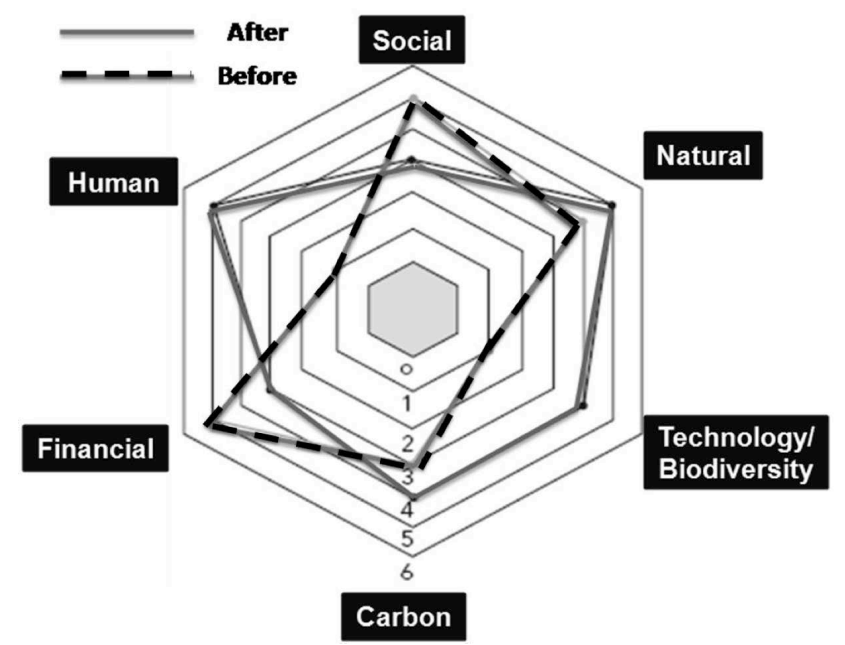

Figure 2. Hexagon - Representation of SCM application results. Adapted from Rezende and Merlin (2003).

ISSN: 07 I8-2724. (http://www.jotmi.org)

Journal of Technology Management \& Innovation (c) Universidad Alberto Hurtado, Facultad de Economía y Negocios. 
After the first evaluation, following each period of credit verification and receipt of the carbon credit revenues, the application of the indicators is performed once again, to verify what has changed in comparison to the previous evaluation.

With this tool, it is possible to identify potentialities to be developed in the project, and develop strategies for the management of the aspects addressed in the evaluation proposed by SCM (Rezende and Merlin, 2003).

\section{Method}

The analysis adopted is based on a multi-agent approach, focusing on the dynamics between the actors involved in the innovation process. This category of participative models introduces the possibility of the involvement of civil society in the decision-making and consultative processes. New institutional arrangements, such as those present in multi-agent models, are characterized by a context of networking which presupposes that organizations are complimentary. In order to attain positive results they have to be able to join forces, thus making the best use of their combined potentials.
In these participatory methods, the model adopted allows the incorporation of stakeholders' perspectives, and also gives incentives to the identification of opportunities for the promotion of innovation in the supply of public services, in this case, those relating to the municipal solid waste sector, as illustrated in Figure 3:

The second methodological procedure is based on the adaptation of the social carbon methodology (SCM), elaborating indicators to assess the social and environmental outcomes of the landfill CDM projects in order to identify opportunities for service innovations relating to solid urban waste. SCM aims to ensure a transparent way to measure the social and environmental profits from GHG reduction projects, by means of monitoring sustainability indicators.

In order to apply SCM, indicators were developed over time for the following sectors: Community Forestry Projects (2003); Landfills (2007); Ceramist Sector Industry (2008); Hydro Power Plants (2008); Micro and Small Hydro Power plant group projects (2010); Methane avoidance through composting in small and medium-sized pig farms (2010); Efficient Lighting Program of activities (PoA) and Bundled Projects (20I I); Fuel Switching Projects (20II).

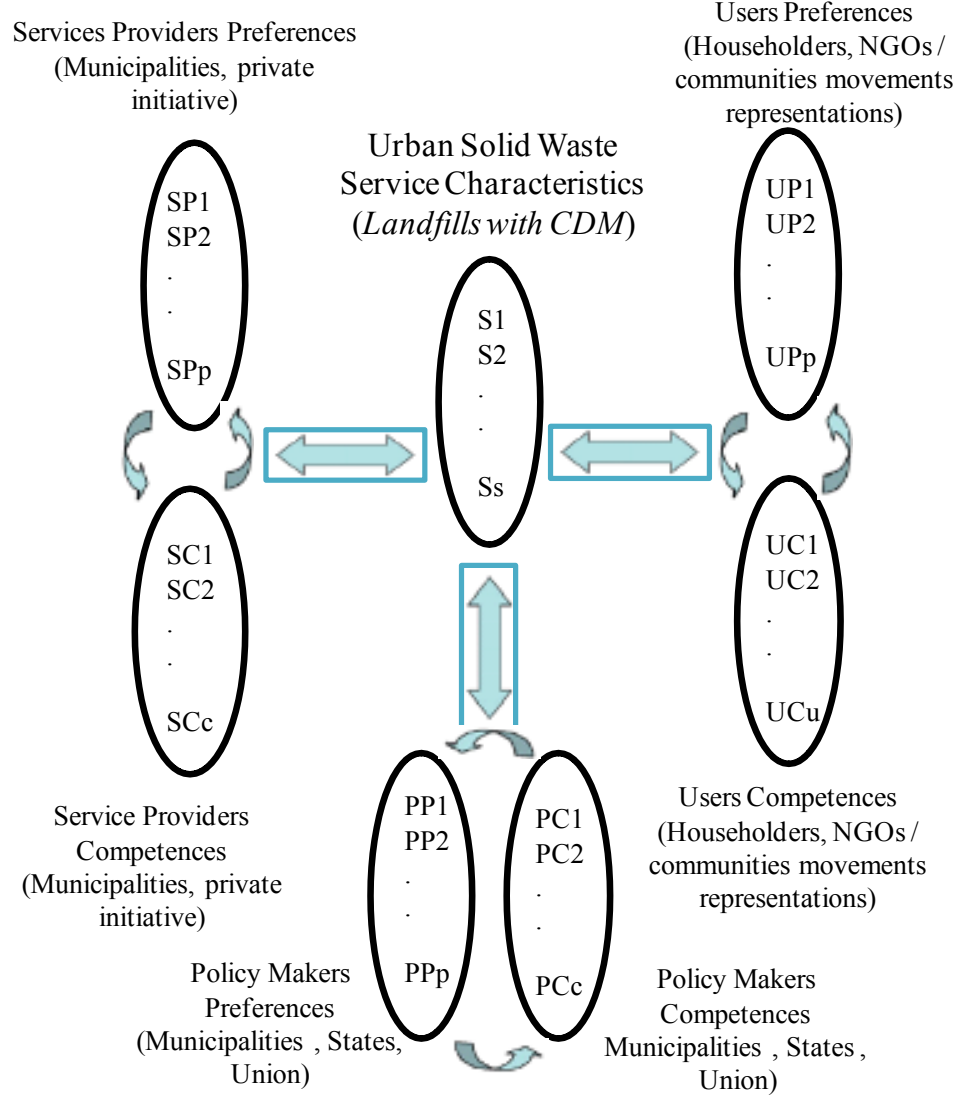

Figure 3. Multi-agent model applied to the urban solid waste sector. The authors, based on Windrum and García-Goni (2008)

ISSN: 07 I 8-2724. (http://www.jotmi.org)

Journal of Technology Management \& Innovation (c) Universidad Alberto Hurtado, Facultad de Economía y Negocios. 
SCM presents indicators at the consultation stage of the approval process for the following fields: Fuel Switching projects (2010); Methane projects (small and medium-sized pig farms) (20I0).

It should be noted that the SCM indicators developed to landfills will not be used in the current research, since we focus on the specific issue of public services innovation through CDM projects and not only on the communities affected by the implementation and operation of landfills involved in GHG emissions reduction projects. Furthermore, SCM indicates the possibility of adapting the indicators for the particular project context in which the methodology will be applied, which makes the evaluation of the local reality more representative.

As examples of projects that adapted the indicators to the local context, we would indicate the following Hydropower Plants in Turkey: Cakit Hydropower Plant Project, Darica-I 99 MW Hydro Power Plant Project, Arca Hydroelectric
Power Plant Project, Multiple Hydroelectric Power Plant Projects, Göktaş-I and II Hydro Electric Power Plant, Gunder HPP Run-of-River Hydro Project, Kepeskaya HPP, Alkumur HPP, and Damlapinar HPP.

The Table 3 lists certified SMC projects around the world. Based on the ability that SCM has to assess the social and environmental sustainability of carbon projects, its adaptation to landfill CDM projects might serve as a tool that helps in that direction, and may also contribute to the identification of opportunities to improve the delivery of municipal solid waste services.

\section{Results}

This section aims to present the results, featuring the landfills studied and identifying the agents involved in the Bandeirantes and São João Landfill CDM projects. Subsequently, the Social Carbon Methodology adaptations for the study are presented, followed by an overview of the indicators developed.

\begin{tabular}{|l|l|l|}
\hline Country & Project scope & $\begin{array}{l}\text { Number of certified } \\
\text { projects }\end{array}$ \\
\hline Brazil & Fuel Switching in Ceramic Industries & 43 \\
\hline Turkey & Hydro Power Plants & 5 \\
\hline Indonesia & Hydro Power Plants & 2 \\
\hline China & Hydro Power Plants & I \\
\hline
\end{tabular}

Table 3. Social Carbon Methodology projects. The authors, based on the data of the Markit Environmental Registry (20I2).

\begin{tabular}{|c|c|c|}
\hline Characteristic & Bandeirantes Landfill & São João Landfill \\
\hline $\begin{array}{l}\text { Year of the beginning of the } \\
\text { landfill operation / closure }\end{array}$ & $1979 / 2007$ & $1992 / 2009$ \\
\hline Tons of waste / day & 5,000 & 6,000 \\
\hline $\begin{array}{l}\text { Project registration Date on } \\
\text { CDM Registry }\end{array}$ & Feb 20, 2006 & Jul 02, 2006 \\
\hline Ist Crediting Period & Dec 03 to $22 \mathrm{Dec} 10$ & May 07 to 21 May 14 \\
\hline $\begin{array}{l}\text { I st Crediting period: average } \\
\text { of GHG emission reduction ( } 7 \\
\text { years) }\end{array}$ & $7,494,404 \mathrm{tCO}_{2} \mathrm{e}$ & $5,718,583 \mathrm{tCO}_{2} \mathrm{e}$ \\
\hline Average $\mathrm{tCO}_{2} \mathrm{e} /$ year & $\mathrm{I}, 070,629 \mathrm{tCO}_{2} \mathrm{e}$ & $816,940 \mathrm{tCO}_{2} \mathrm{e}$ \\
\hline Power plant: Installed capacity & $20 \mathrm{MW}$ & $24.64 \mathrm{MW}$ \\
\hline $\begin{array}{l}\text { Private Concessionary compa- } \\
\text { nies }\end{array}$ & $\begin{array}{l}\text { Concessionary company responsible for } \\
\text { the landfill management; and conces- } \\
\text { sionary company responsible for biogas } \\
\text { recovery }\end{array}$ & $\begin{array}{l}\text { Concessionary company responsible for } \\
\text { the landfill management; and conces- } \\
\text { sionary company responsible for biogas } \\
\text { recovery }\end{array}$ \\
\hline $\begin{array}{l}\text { Municipal waste received over } \\
\text { the years of operation (tons) }\end{array}$ & $37,226,873$ & $26,153,980$ \\
\hline
\end{tabular}

Table 4. Characterization of the Bandeirantes and São João Landfills. Based on UNFCCC (2005a); UNFCCC (2005b)

ISSN: 07 I8-2724. (http://www.jotmi.org)

Journal of Technology Management \& Innovation (C) Universidad Alberto Hurtado, Facultad de Economía y Negocios. 


\section{Landfills characterization and Identification of Agents}

The Bandeirantes landfill is located in the northern region of the municipality of São Paulo, and the São João landfill, in the eastern region of this municipality. The Bandeirantes and São João landfills have distinct characteristics (Table 4).

The application of the multi-agent model, adapted to the context studied, enabled the systematization of the agents identified as stakeholders involved with the Bandeirantes and São João landfill CDM projects, as demonstrated in Table 5:

Based on the stakeholders' identification, sustainability indicators are proposed to evaluate environmental and social local co-benefits.

\section{Design and definition of resources: Social Carbon Methodology adaptation}

To support the construction of sustainability indicators for assessing the contribution of the landfill carbon market projects, three references are proposed: I) Dimensions of sustainability (Social; Environmental; and Economic); 2) Aspects of sustainable development highlighted by resolution $\mathrm{N}^{\circ} \mathrm{I}$ of the Annex III of CIMGC; and 3) The requirements of the $\mathrm{Na}$ tional policy on solid waste (NPSW) Law No. 12,305/2010. Table 6 presents the aspects covered with respect to these references.
Regarding the adaptation of SCM, only four resources of the methodology were used, namely: Social, Natural, Technology, and Carbon, which integrate the sustainability dimensions (social, environmental and economic), as shown in Figure 4:

For this research it was decided not to use the financial resources, originally provided in SCM, since the focus of analysis here was the social and environmental changes caused by the landfill CDM projects in urban solid waste management. With regard to human resources, it was decided to integrate them into social resources, since the aspects analyzed are inextricably linked.

For the economic dimension, only the carbon resource was applied to evaluate the revenue from certified emission reductions (CERs) received by the municipal city hall. In the environmental dimension, the natural and technological resources are allocated. The natural resource deals with the negative environmental externalities generated by the landfill activities, and the technological resource addresses the technical aspects related mainly to the generation / capture of biogas. The social resource seeks, through the indicators, to consider the issues related to training, environmental education activities, as well as the analysis of the coordination and integration among stakeholders linked to the projects. The Table 7 shows the proposed indicators.

In the social dimension, the data generated from the application of the proposed indicators are mainly aimed at highlighting the types of access to benefits related to the

\begin{tabular}{|l|l|}
\hline Sector & Agents \\
\hline Public & Municipal Services Secretariat; and Municipal Secretariat for the Environment. \\
\hline Private & $\begin{array}{l}\text { The concessionary company responsible for the landfill management; and the concessionary company re- } \\
\text { sponsible for biogas recovery and power generation }\end{array}$ \\
\hline Users & Representatives of associations from the communities surrounding Bandeirantes and São João landfills \\
\hline
\end{tabular}

Table 5. Agents involved with the Bandeirantes and São João Landfill CDM projects. Source: The authors.

\begin{tabular}{|l|l|}
\hline References & Covered aspects \\
\hline Sustainability dimensions & Social; Environmental; Economic \\
\hline $\begin{array}{l}\text { Terms of resolution } \\
N^{\circ} \text { I of the Annex III of } \\
\text { CIMGC }\end{array}$ & $\begin{array}{l}\text { Development of working conditions; Generation of jobs; Environmental Sustainability; Technologi- } \\
\text { cal development; Income Distribution; Regional integration; Links with other sectors }\end{array}$ \\
\hline $\begin{array}{l}\text { National policy on solid } \\
\text { waste requirements }\end{array}$ & $\begin{array}{l}\text { Environmental education; Reverse Logistics; Inclusion of cooperatives; Reduction; Reutilization; } \\
\text { Recycling; Proper waste disposal; Dissemination of clean technologies; Energy recovery; Shared } \\
\text { Responsibility }\end{array}$ \\
\hline
\end{tabular}

Table 6. References and aspects addressed in the construction of indicators. Data based on Brazil (2003); Brazil (2010).

ISSN: 07 I8-2724. (http://www.jotmi.org)

Journal of Technology Management \& Innovation (c) Universidad Alberto Hurtado, Facultad de Economía y Negocios. 


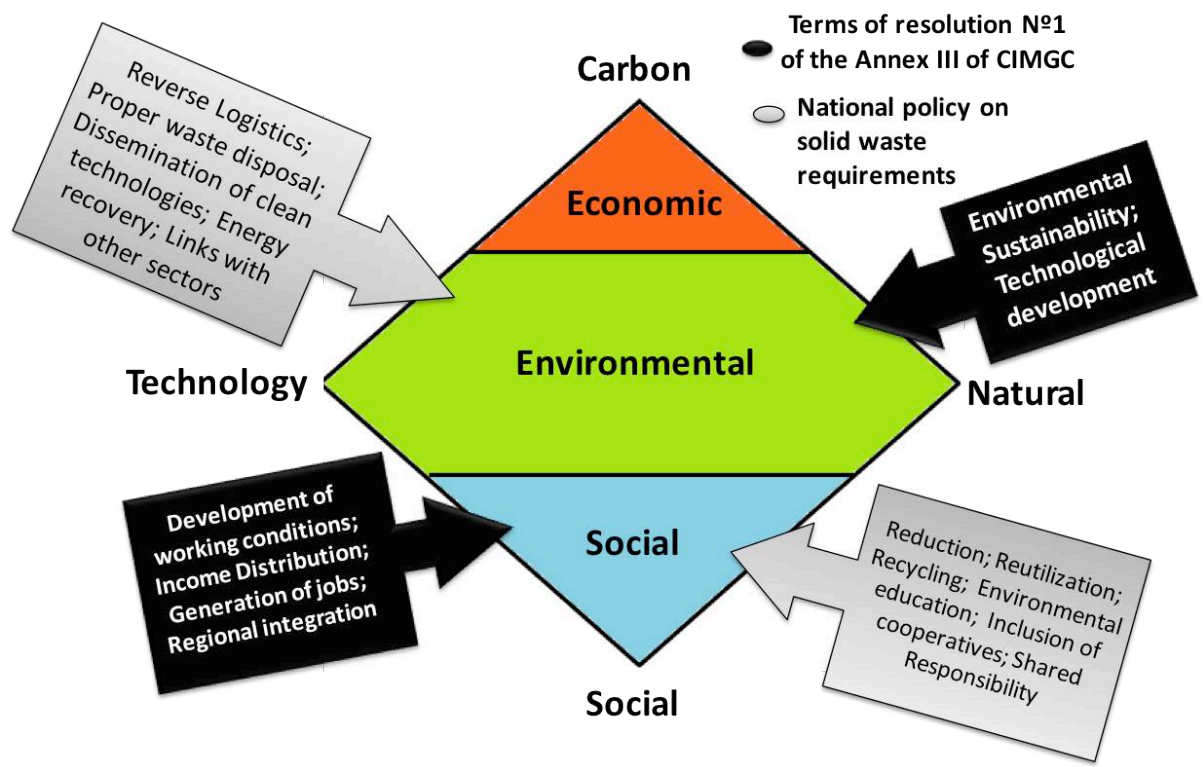

Figure 4. SCM Resources broken down into the sustainability dimensions. Source:The authors

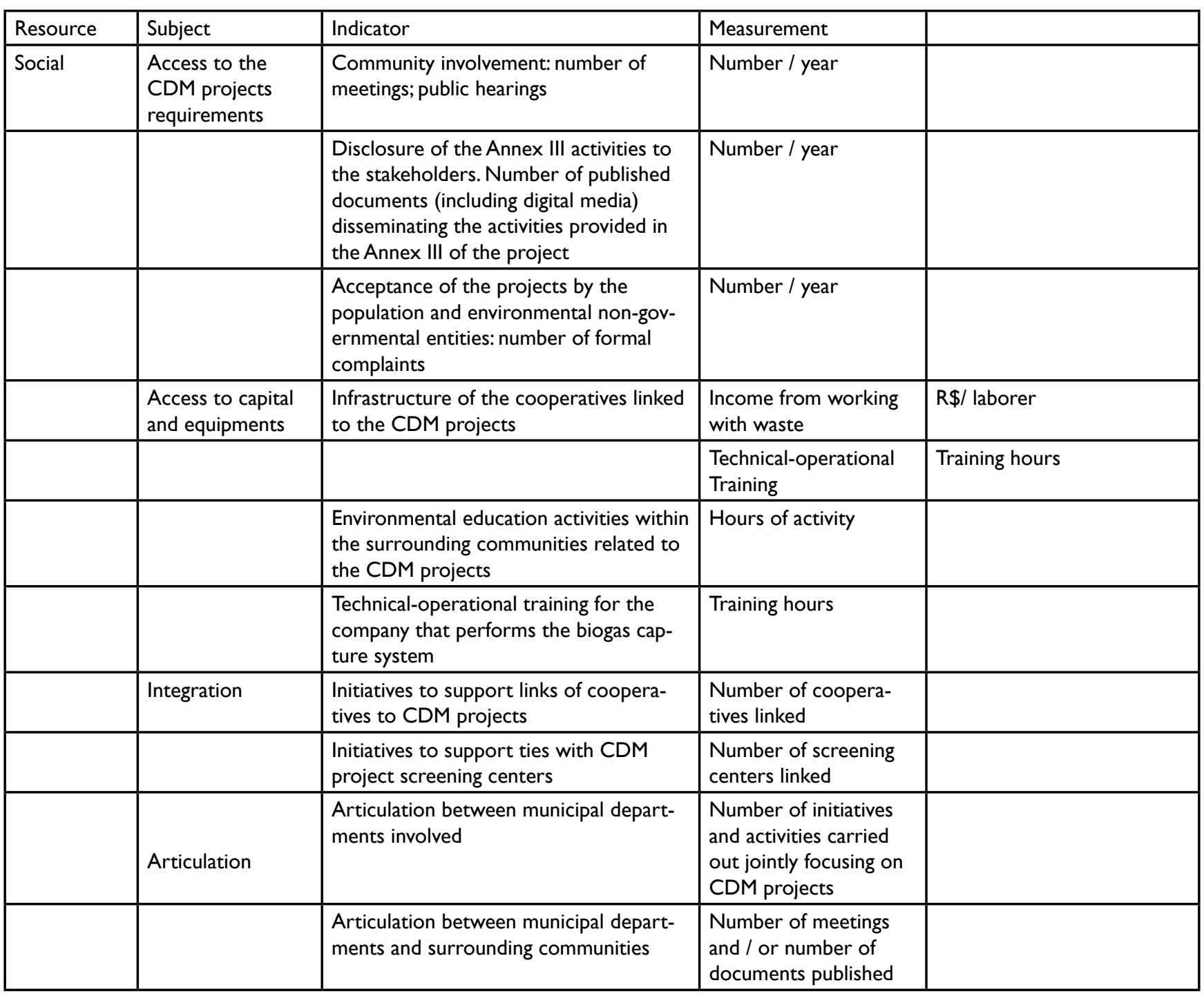

ISSN: 07 I8-2724. (http://www.jotmi.org) 


\begin{tabular}{|c|c|c|c|c|}
\hline & & $\begin{array}{l}\text { Articulation between the company that } \\
\text { manages the landfill and the company } \\
\text { responsible for collecting the biogas } \\
\text { regarding the landfill closure plan }\end{array}$ & $\begin{array}{l}\text { Number of meetings } \\
\text { and / or number of } \\
\text { documents published }\end{array}$ & \\
\hline & & $\begin{array}{l}\text { Articulation between the company that } \\
\text { manages the biogas and the surrounding } \\
\text { community }\end{array}$ & $\begin{array}{l}\text { Number of meetings } \\
\text { and / or number of } \\
\text { documents published }\end{array}$ & \\
\hline \multirow[t]{6}{*}{ Natural } & $\begin{array}{l}\text { Landfill deactiva- } \\
\text { tion }\end{array}$ & Landfill closure plan & $\begin{array}{l}\text { \% Compliance with the } \\
\text { targets established in } \\
\text { the initial design of the } \\
\text { landfill }\end{array}$ & \\
\hline & & Reforestation area & $\begin{array}{l}\text { Reforested } \mathrm{m}^{2} / \text { total } \\
\text { area of the landfill }\end{array}$ & \\
\hline & $\begin{array}{l}\text { Management and } \\
\text { Control }\end{array}$ & $\begin{array}{l}\text { Frequency of soil restoration on the } \\
\text { cells }\end{array}$ & Rearrangements /year & \\
\hline & & Geotechnical monitoring frequency & Sample/year & \\
\hline & $\begin{array}{l}\text { Sampling outside } \\
\text { the standards }\end{array}$ & $\begin{array}{l}\text { Frequency of monitoring underground } \\
\text { water }\end{array}$ & Sample/year & \\
\hline & & $\begin{array}{l}\text { Frequency of monitoring surface and } \\
\text { underground water }\end{array}$ & Sample/year & \\
\hline \multirow[t]{4}{*}{ Technology } & $\begin{array}{l}\text { Air emissions } \\
\text { quality }\end{array}$ & Fugitive gas emissions & Vol/year & \\
\hline & & Biogas collection & Vol/year & \\
\hline & & Frequency of odors monitoring & samples/year & \\
\hline & $\begin{array}{l}\text { Technical and } \\
\text { environmental }\end{array}$ & Condensed & $\begin{array}{l}\text { Volume of biogas } \\
\text { condensate treated } \\
\text { or recirculated to the } \\
\text { landfill / total volume of } \\
\text { biogas condensate }\end{array}$ & \\
\hline \multirow[t]{2}{*}{ Carbon } & - & CERs generated & $\%$ MR/PDD & \\
\hline & & $\begin{array}{l}\text { Commitment of the CER revenue in } \\
\text { Programs - Activities / USW Projects }\end{array}$ & $\begin{array}{l}\text { \% committed value / } \\
\text { updated budget }\end{array}$ & \\
\hline
\end{tabular}

Table 7. Sustainability Indicators. Source:The authors.

development of CDM projects by the users, surrounding communities, and recyclable material collectors. The term "articulation" was used for the involvement of the stakeholders because these actions are in an embryonic stage. However, it is intended, at a later stage, that these links will develop and become something capable of being formalized through agreements, for example.

In the environmental dimension, the indicators are intended to provide data on the contribution of CDM projects to reduce the negative externalities related to landfills. And in the economic dimension, the financial resources generated by the projects are measured, as well as their employment in actions or activities directly aimed at co-generation of environmental and social local benefits in the solid waste sector.

\section{Final considerations}

The analysis of innovation in public services needs, a priori, to try to understand the multi-faceted and heterogeneous nature of this sector, involving multiple stakeholders, given that part of this nature is a result of their multiple interfaces: with the private sector; between the public sector and citizens; and the internal interfaces of the public sector.

The application of the multi-agent model for public service innovation makes it possible to draw together all the political actors, service organizations and consumers / users.

Since sustainable development is a process of continuous improvement, it is necessary not only to perform the monitoring of GHG emission reductions, but also, to monitor the generation of local social and environmental co-benefits

ISSN: 07 I8-2724. (http://www.jotmi.org) 
from carbon market projects. In this sense, the pertinence was established of the application of the resources on which SCM is based for the generation of indicators (Social, Natural,Technology, and Carbon) in order to grasp the particularities of the service offered in the context researched. Both with regard to the opportunities to construct new ways to solve particular problems, by means of new institutional and organizational arrangements - involving municipal governments, utility companies, communities surrounding the landfills, recyclable material collectors and organized bodies of civil society - as well as with respect to the establishment of indices and parameters to guide the objectives of innovation in the public sector.

\section{References}

BHATTA, G (2003). Don't just do something, stand there! Revisiting the issue of risks in innovation in the public sector, The Innovation Journal: The Public Sector Innovation Journal 8(2) I2p .

BELLEN, H. M. V. (2006). Indicadores de Sustentabilidade: Uma análise comparativa. Rio de Janeiro: Ia. ed. Editora FGV.

BRAZIL. (2003) Comissão Interministerial de Mudanças Globais do Clima - CIMGC, Resolução n.I de II de setembro de 2003.

BRAZIL. (20II) Comissão Interministerial de Mudanças Globais do Clima - CIMGC. Status atual das atividades de projeto no âmbito do Mecanismo de Desenvolvimento Limpo (MDL) no Brasil e no mundo: Última compilação do site da CQNUMC 3I de janeiro de 20II. http://www.mct.gov. br/upd_blob/0215/2I5I86.pdf [Accessed March I4, 2013].

BRAZIL. (1997) Protocolo de Kyoto à Convenção sobre Mudança do Clima. Editado e traduzido pelo Ministério da Ciência e Tecnologia - MCT com o apoio do Ministério das Relações Exteriores. http://www.mct.gov.br/upd_ blob/00 12/I2425.pdf [Accessed March 14, 2013].

BRAZIL. (2010) Lei n 12.305, Política Nacional de Resíduos Sólidos, de 2 de agosto de 2010.

BUGGE; M.; Bloch, C.; Hauknes, J:; Slipersaeter, S. (2010). The public sector in innovation systems, Module I - Conceptual Framework, MEPIN project.

$\mathrm{KOCH}, \mathrm{P}$; Hauknes, J. (2005). Innovation in the public sector. Report no D20. Publin project under the EU 5th Framework Programme. Oslo: NIFU STEP.

MULGAN, G.;Albury, D. (2003) Innovation in the Public Sector, Strategy Unit, London: Cabinet Office Strategy Unit, UK Cabinet Office, October.
OCDE (1993). Organization for economic cooperation and development: core set of indicators for environmental performance reviews; a synthesis report by the group on the state of the environment. Paris: OCDE.

POOTS, J. (2009). The innovation deficit in public services: The curious problem of too much efficiency and not enough waste and failure, Innovation: Management, policy \& Practice, Volume II, Issue I, April, 34-43.

POTTS J.; Kastelle, T. (2010). Public sector innovation research: what's next? Innovation: Management, Policy \& Practice I2(2): 122-137.

REZENDE, D; Merlin, S. (2003). Carbono Social: Agregando valores ao desenvolvimento sustentável. Organização Andre Sarmento. Peirópolis, Brasília, DF. Instituto Ecologica.

RODRIGUES, G. S.; Campanhola, C.; Kitamura, P. C. (2003). An environmental impact assessment system for agricultural R \& D. Environmental Impact Assessment Review, v. 23, n. I, 219-244

SCOONES, I. (1998). Sustainable rural livelihoods: a framework for analysis. IDS working paper, Brighton (UK), n. 72, $\mathrm{I}-22$.

SOCIALCARBON (2003). Indicators for Forest Projects, Version 2.I. http://www.socialcarbon.org/documents/ [Accessed March I4, 20I3].

SOCIALCARBON (2007). Indicators for Landfill, Version I.I. http://www.socialcarbon.org/documents/ [Accessed March 14, 20I3].

SOCIALCARBON (2008). Industries of the Ceramic Sector, Version 8.2. http://www.socialcarbon.org/documents/ [Accessed March 14, 2013].

SOCIALCARBON (2008). Indicators for Hydropower Plants, Version 4.I. http://www.socialcarbon.org/documents/ [Accessed March 14, 20I3].

SOCIALCARBON (2010). Indicators for Micro and Small Scale Hydropower Grouped Project, Version I.I. http:// www.socialcarbon.org/documents/ [Accessed March 14, 2013].

SOCIALCARBON (2010). Indicators adapted for Cakit Hydropower Plant Project, Turkey. http://www.socialcarbon. org/documents/ [Accessed March 14, 20I3].

SOCIALCARBON (2010). Indicators adapted for Darica-I 99 MW Hydro Power Plant Project, Turkey. http://www.socialcarbon.org/documents/ [Accessed March I4, 20I3].

ISSN: 07 I8-2724. (http://www.jotmi.org) 
SOCIALCARBON (2010). Indicators for Fuel Switching Projects, Brazil, version I. http://www.socialcarbon.org/documents/ [Accessed March 14, 20I3].

SOCIALCARBON (2010). Methane avoidance through composting in small and medium sized swine farms, Brazil. http://www.socialcarbon.org/documents/ [Accessed March I4, 20I3].

SOCIALCARBON (20II). Indicators for Indicators for Efficient Lighting PoA and Bundled Projects, Version 1.0 http:// www.socialcarbon.org/documents/ [Accessed March 14, 2013].

STOKER, G. (2010). Translating experiments into policy, Annals of the American Academy of Political and Social Science 268: 47-58.

SUNDBO, J. (20I0). Public-Private innovative networks in services: Does entrepreneurship matter?, Centre of services studies, Roskilde University, Denmark.

UNEP RISOe (20I3). Capacity Development for the CDM, CDM projects in the pipeline Analysis and Database, March 2013. http://www.cd4cdm.org/ [Accessed March 14, 20I3]. UNFCCC (2005a) United Nations Framework Convention on Climate Change. Project Design Document: Bandeirantes Landfill Gas Project. http://cdm.unfccc.int/ [Accessed January 15, 2013].

UNFCCC (2005b) United Nations Framework Convention on Climate Change, CDM Executive Board. Project Design Document: São João Landfill Gas Project. http://cdm.unfccc. int/ [Accessed January 15, 2013].

WINDRUM, P.; García-Goñi, M. (2008). A neo-Schumpeterian model of health services innovation, Manchester Metropolitan University Business School, Center for International Business \& Innovation, Manchester, UK, Research Policy 649-672. 